\title{
Speech therapy students' attitudes to the use of ICTs in speech therapy practice
}

ABSTRACT: Justyna Wiśniewska, Speech therapy students' attitudes to the use of ICTs in speech therapy practice. Interdisciplinary Contexts of Special Pedagogy, no. 30, Poznań 2020. Pp. 223-241. Adam Mickiewicz University Press. ISSN 2300-391X. e-ISSN 2658-283X. DOI: https://doi.org/10.14746/ikps.2020.30.11

The article presents research results on the possibility of using ICTs in a speech therapist's practice. The results of the study show that students have changed their view of the place of ICTs in speech therapy. The COVID-19 pandemic has changed their attitudes towards ICTs. For them, this crisis has become an opportunity for the development of their own skills to use ICTs in their future professional work.

KEY WORDS: speech therapy, attitudes, opinions, students, collective case study, information and communication technologies, distance learning, remote learning

\section{Introduction}

The situation triggered by the COVID-19 pandemic has forced most educational institutions to adopt a new mode of operation, make greater use of information and communication technologies (ICTs), mainly for distance education. Until recently, this was just an option and now is the only way to deliver educational and therapy sessions. ${ }^{1}$ Pursuant to the Regulation of the Minister of National

${ }^{1}$ J. Pyżalski, Wstęp, [in:] Edukacja w czasach pandemii. Z dystansem o tym, co robimy obecnie jako nauczyciele, Ed. J. Pyżalski, EduAkcja, Warsaw 2020, p. 2. 
Education of 20 March 2020, educational institutions, including pedagogical and psychological counselling centres, have transitioned to a system of distance work. ${ }^{2}$ Psychologists, educators, therapists, speech therapists came to face an extremely difficult challenge. They needed to quickly learn to use new information and communication technology tools in therapy, acquire new skills and improve their digital competence. The need to suddenly switch to remote therapy was a huge challenge for many.

The situation of speech therapists seemed to be particularly difficult due to the distinctive nature of speech therapy. The reeducation of speech disorders requires, among other things, the use of: manual support for vocal organs during speech, mechanical methods (the use of, e.g., a spatula or a vibrator to assist the child in producing clean sounds) and the supervision of the proper positioning of articulatory organs. It is difficult to deliver these tasks while interacting with a child through a web app. The challenges faced by practicing speech therapists, as well as speech therapy students, who also had to deliver speech therapy sessions remotely to complete their internships, prompted the author of this article to explore the issue and conduct this research project.

\section{ICTs in speech therapist's practice}

The attempts to use ICTs in speech therapy have been made almost since computers first appeared in Poland. ${ }^{3}$ Józef Surowaniec, the originator of Logopeda, the first computer system supporting speech therapy diagnostics and speech therapy practice, would write about computers as a tool that can raise the effectiveness of

2 The Regulation of the Minister of National Education of 20 March 2020 on special solutions in the period when operation of educational institutions needs to be temporarily limited to prevent, counteract and combat COVID-19. (Journal of Laws 2020 no. 493).

3 See, among others: B. Siemieniecki 1999; S. Juszczyk, W. Zając 1997; J. Łaszczyk 1998. 
speech therapy as early as the 1990s. ${ }^{4}$ He had great hopes for the computer. He believed that over time it would become a handy tool for scientific, educational and practical work of speech therapists. ${ }^{5}$ After almost 30 years, can we say these hopes have come true?

The offices of today's speech therapists are usually equipped with a computer with appropriate software. It is today's standard practice to use a computer to keep records. Speech therapists develop plans, reports, opinions, project outlines, research results and information for parents and teachers in the form of digital files. Some successfully use commercial licensed multimedia computer applications to make their therapy sessions more attractive. The research conducted by Mateusz Szurek ${ }^{6}$ shows that the majority of the surveyed speech therapists $(84 \%, 32$ individuals) consider the use of multimedia in speech therapy justifiable. The respondents pointed out that computer games are associated with pleasure and fun, engage children emotionally and help them keep their attention for longer. Nevertheless, those speech therapists use this form of work on average once every three meetings (84\%, 32 individuals) and spend mostly 5-10 minutes (45\%, 17 individuals) in 45-60 minutes of a therapy session on exercise with multimedia games. ICTs are thus used to add some variety to their therapy sessions and make them more attractive, and are a kind of encouragement or reward.

However, the previous body of research has shown that they not only increase the attractiveness of therapy sessions, but can also

${ }^{4}$ In 1988-1990, a research project was conducted under the Ministry's Research and Development Programme as regards software for a computer system that would support speech therapy diagnostics and practice, called Logoped (see J. Surowaniec, Dekada informatyczna w rozwoju polskiej logopedii 1986-1996, Logopedia No. 23/1996, p. 184).

${ }^{5}$ J. Surowaniec, Zastosowania informatyki w logopedii, [in:] Opuscula Logopaedica: in honorem Leonis Kaczmarek, Ed. S. Grabias, L. Kaczmarek, Wydawnictwo UMCS, Lublin 1993, p. 118.

${ }^{6}$ Cf. M. Szurek, Czy wspótczesny logopeda powinien wykorzystywać multimedia w terapii logopedycznej?, [in:] Zastosowanie nowych mediów w edukacji dzieci i młodziė̇y, Ed. E. Brzyszcz, S. Koziej, Uniwersytet Jana Kochanowskiego, Kielce 2017, pp. 133-143. 
be very effective. ${ }^{7}$ This way of work stimulates a child's emotional and motivational apparatus, supports their commitment, curiosity and interest, and alleviates boredom and discouragement. ${ }^{8}$ The results of a study carried out by Krystyna Żuchelkowska showed that educational computer apps have a significant effect on the development of correct pronunciation in preschool children. ${ }^{9}$ She recognizes the following advantages of using computers in speech therapy practice: 1) a computer does not get angry, is not spiteful, does not comment on child's actions, 2) allows the same exercise to be performed many times, 3) a correctly performed exercise is rewarded with a pleasant sound effect or an interesting and sometimes funny animation, 4) a computer delivers difficult content with colourful graphics, animations and sound effects, 5) it encourages children to perform auditory, respiratory and articulatory exercises, which significantly contribute to nurturing correct pronunciation. ${ }^{10}$

Today's speech therapists can also take advantage of the possibilities offered by the Internet. ${ }^{11}$ Speech therapy websites offer access to flashcards, among other things. Once printed, they can be used with a child during an office-based therapy session or given to the child for a homework assignment. An example of wider use of

7 Cf., among others: Jatkowska 2018; Waligóra-Huk 2015; Żuchelkowska 2015.

8 B. Siemieniecki, Zastosowanie technologii informacyjnej w pedagogice specjalnej, [in:] Pedagogika medialna, Vol. 2, Ed. B. Siemieniecki, Wydawnictwo Naukowe PWN, Warsaw 2007, p. 58.

9 The research concerned the effect of educational computer apps on the development of correct pronunciation in pre-school children. The survey group consisted of 100 6-year-old children attending preschool centres. The primary research method employed was an educational experiment conducted with the technique of two parallel groups, based on the canon of difference (cf. K. Żuchelkowska 2015, p. 332).

${ }^{10} \mathrm{~K}$. Żuchelkowska, Edukacyjne programy komputerowe w kształtowaniu prawidtowej wymowy u dzieci, [in:] Edukacja a nowe technologie w kulturze, informacji $i$ komunikacji, Ed. D. Siemieniecka, Wydawnictwo Naukowe Uniwersytetu Mikołaja Kopernika, Toruń 2015, pp. 330-331.

11 Some websites: https://www.printoteka.pl/pl/materials/category/1; https:/ / www.logopestka.pl/; https://domologo.pl/ 
the possibilities of the Internet is the first e-learning platform for speech therapy practice in the Polish market, launched in 2009. Its developer Joanna Jatkowska came up with the idea of e-logolessons ${ }^{12}$, posted on the platform to complement regular meetings with a speech therapist. The said pedagogical experiment showed that for children with simple or multiple dyslalia this form of work reduces the duration of therapy and the number of face-to-face meetings between the speech therapist and the child, increases parent's involvement and helps to deliver the commitment to do speech therapy exercises at home. ${ }^{13}$

New technologies can successfully support speech therapists and make therapy more effective and enjoyable, but this requires not only the preparation of appropriate tools, but also speech therapists having adequate digital skills. Such skills should be acquired by speech therapists during their studies.

\section{Computer training for speech therapy students}

The relevant regulation by the Minister of National Education on the standard of training one needs to complete to pursue, among others, the career of a speech therapist envisages the obligation to provide at least one subject concerning ICTs in the study curriculum, a total of 30 hours. ${ }^{14}$ As a rule, this is the first-year course and primarily aims to prepare students to develop their graduation projects and process and present the results of their empirical research.

12 A b-learning model was used here, whereby, between traditional meetings with a speech therapist in the office, the child does exercises assigned to them by the speech therapist on the e-learning platform, under their parent's supervision. Since the therapist was able to record the child's voice while they were doing the exercises, they would review the recordings and provide them with relevant comments (cf. J. Jatkowska 2018, pp. 131-132).

13 J. Jatkowska, Rozwój językowy dziecka a b-learning, [in:] Annales Universitatis Paedagogicae Cracoviensis. Studia de Cultura, Vol. 10, No. 4/2018, pp. 134-136.

14 The Regulation No. 3 of the Minister of National Education of 25 July 2019 on the standard of training for teaching practice (Journal of Laws 2019 no. 1450). 
In practice, this means that students have little chance to learn how to support speech therapist's practice with information and communication technologies. Some universities, however, go beyond the minimum requirement defined by the regulation. This is the case with the Academy of Special Education, where speech therapy students have two general subjects of this kind in their study curriculum: Computer Science (classes in the first year, 30 hours) and Modern Technologies in Pedagogical Practice ( $3^{\text {rd }}$-year class, 15 hours). Despite the possibilities offered by the university, the author's many years of experience as a lecturer show that speech therapy students are not very positive about these classes. The early meetings with these groups are always difficult. Early on, the students do not recognize the need to acquire the skills offered to them, although teachers always prioritize the content useful for future professional practice in structuring their courses. During the Modern Technologies in Pedagogical Practice course, speech therapy students explore the possibilities of using ICTs in educational practice. They acquire the skills to use an interactive whiteboard, and design interactive exercises with the help of web applications (e.g. LearnigApps $^{15}$, WordWall ${ }^{16}$, WordArt ${ }^{17}$, Genially ${ }^{18}$, Quizziz ${ }^{19}$ ). They create their own interactive resources and develop skills needed to deliver therapy sessions with the use of those resources. Additionally, during this year's classes, due to the situation in Poland, the students had the opportunity to learn to conduct remote therapy with the use of applications such as Padlet ${ }^{20}$ and Smart Learning Suite Online. ${ }^{21}$

Although these applications have not been designed for the work of a speech therapist, they are so universal (and also available to the public free of charge) that they can be successfully used to

\footnotetext{
15 https:/ / learningapps.org/

16 https://wordwall.net/pl/

17 https:/ / wordart.com/

18 https://www.genial.ly/

19 https:/ / quizizz.com/

${ }^{20}$ https://padlet.com/

21 https://suite.smarttech-prod.com/login
} 
prepare digital materials to be used in speech therapy sessions with children or support parents in performing exercises recommended by the speech therapist.

\section{Research methodology}

The goal behind this study was to investigate speech therapy students' attitudes towards ICTs used in speech therapy. Three research problems have been formulated:

- What was the initial approach of speech therapy students towards the possibility of using ICTs in speech therapy?

- How has the students' view of how useful the ICTs are in speech therapy changed as a result the classes on Modern Technologies in Pedagogical Practice and first-hand experience delivering speech therapy sessions online?

- What plans do the speech therapy students declare for the use of ICTs in their speech therapy practice?

In order to address the defined research problems, a multiplecase study strategy has been adopted, which involves examining a number of cases to investigate a general phenomenon ${ }^{22}$. The data has been collected by means of two different methods. The first method used was an open auditorium questionnaire, for which an original questionnaire was developed. The second method was an in-depth, individual, structured interview, using a proprietary interview questionnaire, with the respondent being openly notified about the aim of the project. The research was conducted from April to June 2020 by means of ICT tools.

The project involved 11 participants, all female $3^{\text {rd }}$-year speech therapy students (a full-time programme) who had attended the classes in Modern Technologies in Pedagogical Practice in the academic year 2019/2020. According to the study plan for the third

22 R.E. Stake, Jakościowe studium przypadku, Trans. M. Sałkowska, [in:] Metody badań jakościowych. T. 1, Ed. N.K. Denzin, Y.S. Lincoln, Wydawnictwo Naukowe PWN, Warsaw 2020. 
year, the students had to complete a graduation internship and a mid-year internship, during which they conducted individual speech therapy sessions with children manifesting various speech disorders. As some of these internships were carried out at the time educational institutions were being closed down due to the epidemic, most of the students had to complete their speech therapy internships remotely.

\section{Analysis of author's research results}

The data collected in the course of the conducted research project provided many valuable insights into how the role of ICTs in speech therapy is viewed by young people about to launch their speech therapy careers. These insights have been structured and analyzed with regard to the research problems. Further herein, they will be presented in the order of the research questions asked.

\section{The initial approach of speech therapy students towards the use of information and communication technologies in speech therapy practice.}

Before attending the classes in Modern Technologies in Pedagogical Practice, the students declared little familiarity with web applications that could be useful for their future professional work. When asked about their familiarity with such applications, 5 of them stated that they did not know them at all, the others mentioned Kahoot (3 mentions), Quizlet (2 mentions), Wordwall (1 mention). Their familiarity with web resources (social media profiles, blogs, websites), which they mentioned as the sources of materials useful for their future professional practice, looked better. The students mentioned: Facebook groups (Wszystko o Logopedii, Logopedki bez hejtu, Teczka logopedy, Logopedia - terapia zaburzeń mowy), blogs (https:/ /logopedarybka.pl/, https://matkalogopedka.blogspot. com/, http://bubagada.pl/, http://logomama.pl/), strony internetowe (https://www.printoteka.pl/, https://www.mimowa.pl/, https://domologo.pl/, https://www.logopediapraktyczna.pl) 
The answers from the students regarding the question about their attitude towards ICTs implied skepticism. Their statements featured some aversion to technology, a belief that technology has only an adverse effect on children, the belief that the later children start using digital tools, the better.

"I used to view the Internet as an enemy, I was aware of the negative impact of electronic devices on children's concentration. Aware of the growing rate of young patients using sensory integration therapies, corrective gymnastics and ophthalmologists' services, I thought the children would have been fine if they just had played in playgrounds, sandboxes and climbed some trees. This would allow their joints and central nervous systems to develop properly. But now I know you cannot take technology away from the little ones. The role of educators and a carers is not to take them away; instead, they should teach kids to make a good use of the possibilities offered by the Internet". (S4)

The students' initial reluctance may also be due to the lack of previous positive experience or the fact that they have not been exposed to good practices in using ICTs for speech therapy practice. Only one of the students mentioned that she had the opportunity to learn about multimedia speech therapy apps during her internship.

"So far I have been exposed to and used only traditional forms of speech therapy assignments without the use of ICTs. (...) I didn't even think there could be any free applications that let you create your own speech therapy tasks," (S8)

"Only on a few occasions have I been exposed to the use of ICT technologies in speech therapist's practice. Most of the speech therapists I had my internships with would work in a regular way, with board games and cards. The children would occasionally practice with the use of a speech therapy app and it was clear they liked this work method a lot. I think that computer-based exercise is more interesting, more attractive to children". (S10) 
It is often the case that the students believe their digital competences are low, which is a noteworthy factor. They wrongly believe that it is difficult to design educational multimedia aids, and mastering apps that will let speech therapists design their own interactive exercises is time-consuming and beyond their capability.

"Until now, I have believed it would be very difficult to create any task in a computer application". (S5)

"Until now, information and communication technologies have been alien to me. It seemed to me that it was very difficult to create and prepare therapy sessions with ICTs and it would require extensive knowledge of IT apps. I used to believe that, as far as speech therapist's practice is concerned, it was impossible to design therapy sessions in multimedia or web applications, and that the child's work with the use of such an app would be ineffective". (S9)

2. How the attendance to Modern Technologies classes and an experience running online therapy sessions have affected the students' view of the possibility of using ICTs in speech therapy work, based on students' responses.

After attending classes on the use of modern technologies in pedagogical work, all students said that they had learned about many useful apps. They believe these apps can make therapy more attractive and support the need to repeat a given exercise a number of times in order to consolidate correct pronunciation, something children find tedious. Performing such exercises by means of digital devices can, in their view, partially solve this problem.

"This form of exercises provides the child with greater variety, something interesting. Generally, speech therapy sessions should be colourful, varied and original. So why not introduce applications and technology into everyday life?" (S3)

The students have also changed their minds about the difficulty of preparing digital aids by means of web applications. They viewed these applications as accessible and easy to use. 
"I think these classes have given me an overall idea of how technology around us can be used. I had no idea about some of the apps and I thought they were much more difficult to use, but it turned out to be much simpler than I used to think. (S10)

"I am surprised how easy it is to design individual exercises in the apps discussed in the classes and how much I enjoy creating them". (S9)

Some of the students' statements show that these classes have been very useful and practical.

"That was one of the most practical subjects taught at the university this semester - considering how useful it is for speech therapy practice". (S6)

These classes have strongly contributed to my professional growth and "(...) stimulated my creativity and joy in creating speech therapy aids". (S2)

"(...) I have changed my view of this issue. I believe that developing such therapy activities can be very creative for the speech therapist and make them grow, and that there are many positive aspects for children who participate in such activities. (S9)

According to students, the acquisition of independent skills to design interactive exercises helps them design exercises that are more individual and better tailored to a child's particular needs. Using a child's favourite fairy tale character in the designed exercise makes things more personalized, and the child can feel more encouraged to show effort and exercise. This will definitely support the effectiveness of therapy.

"Having completed these classes (...), I know you can create these exercises on your own and tailor them to each child's needs. From the beginning, I thought it was a great idea for the activities with children. (S3)

One of the students also observed "that this is a convenient and economical solution - it reduced the costs for the production of aids and lets you 'store' them in one place". (S2) 
The situation that they have faced has had a major impact on changing students' attitudes towards the possibility of using ICTs in speech therapy. Due to the pandemic and the decision to close educational establishments, the students had to complete their internships by conducting remote therapy with their clients. Only one student had completed her internship before the pandemic was announced. Since it was not possible to continue traditional meetings with children, the other students had to deliver therapy remotely. Each of them conducted one-on-one therapy sessions with 1-3 children (the number of children with whom the students conducted therapy depended on the progress of the internship at the time the educational institutions were closed down). Most of them used instant messengers to this end (e.g. Skype, Messenger, Whatsapp, the video communication functionality on Facebook). They were very flexible about their app choices; they picked those that were available to the children's parents (one of the students would use 3 different apps to deliver her speech therapy sessions). Meetings in the form of video calls were usually held 1-2 times a week. Parents did not agree to this form of therapy for organizational reasons only in two cases; instead, they asked students to e-mail them the materials for them to use with their children.

The students' statements show that the use of digital tools to deliver therapy sessions has been a positive experience to them. While using selected communication apps to talk with children, the students made use of the extra features of those apps such as screen sharing to display pictures or to send links to pre-prepared interactive exercises within the chat window.

"(...) I have already tested in practice some of the apps I have learned about - during online therapy sessions with a child, on a video call. With the screen sharing feature, I could display the tasks together with my client while at the same time checking if she completed them well". (S1)

"In the current situation (...) this is an ideal alternative to standard speech therapy aids. When I cannot show an aid to a child in person or use cards or board games, I can send them an aid designed in an app. 
In addition to sending the client printable speech therapy aids, I have also sent them assignments based on Learningapps, Wordart, Quizizz and Smart Notebook. The children liked these kinds of aids a lot, and they are an interesting feature of our online sessions". (S2)

"I use the applications I have learned about in that I talk to the child on Skype (...) The screen sharing option can be useful (...) as the child and the teacher can see the same image on the screen while the child is carrying out assignments (...). As for the tasks I design, the child first has to click, tick or answer a question, and then read a syllable, word or word combination out loud. By means of a webcam, I can supervise the child's completing a given task, I can watch the child doing it and ask them to correct something". (S6)

Delivering online therapy, the students also noticed another advantage behind their ability to design exercises with publicly available web apps. They argued that these exercises are available to both therapists, children and their parents, as opposed to expensive licensed software used at speech therapy practices. Moreover, as one of the students claims:

"Although it may appear otherwise, there are not many free speech therapy aids on the Internet. Thanks to the applications, we can create them ourselves". (S2)

The students have also observed a very positive response from children to the new form of therapy; they claim that children's interest and focus during the classes have increased.

"My client has great difficulty in focusing her attention. Even before the pandemic, when I had delivered therapy at her house, I had to try very hard (...) to make her want to do what I asked her to do in our practice, and now with online tasks, she can (...) practice with me even for half an hour, which was impossible before'. (S1)

Those students who have been providing remote therapy to children accompanied by their parents have also noticed a greater 
involvement of parents in the therapeutic process. The parents became more attentive to their child's speech, and it was easier for them to correct their children's speech on a daily basis.

The statements quoted so far demonstrate that students' attitudes towards new technologies have changed and they have recognized the role of those tools in speech therapist's practice. Their statements are marked by greater pragmatism. The students are afraid that too much use of interactive exercises comes with the risk that children may become discouraged to traditional working methods. They also see other risks:

"I don't believe it's right to send multimedia tasks for children to perform at home on their own, because it does not allow me to track the therapy progress and whether the child correctly consolidates specific sounds". (S1)

"(...) this adds some variety and is certainly more interesting for the child, but I wouldn't rely solely on it, because children already have too much contact with technology on a daily basis". (S11)

The disadvantages they see in online therapy are: the manual methods cannot be used (sometimes it is possible to ask the parent for support, but this is not always possible); it is hard to precisely determine the quality of sounds realized by the child (especially with pronunciation deficiencies that consist in deformed sounds), and child's tongue movements are less visible. They also exclude the possibility of diagnosing the child in this mode.

"Many children need facial muscle massage, resistance exercises for their tongue muscles, as well as exercises for large motor skills. Unfortunately, we cannot do this remotely. Moreover, I cannot imagine delivering a speech therapy diagnosis without being in the same room with the patient". (S4)

"I will not start online work with a child who I have not seen before in person to diagnose them and set their therapy plan". (S4) 
Despite the many advantages behind the use of modern technologies in speech therapy, students' views are very balanced. They are aware of the place and role of ICTs in the speech therapy process. They think of them as a tool that supports the work of speech therapists. They stress that these technologies cannot be a substitute for traditional working methods.

"To some extent though. The computer shall not replace the specialists". (S3)

"In my opinion, however, tasks on the computer/tablet should not dominate the activities. Self-control is extremely important in practicing proper articulation, and the mirror is the basic tool with this practice. In using multimedia apps, a child is not able to fully focus and control their speech organs. I believe, however, that such exercises can be used in many different ways, and I will certainly use them in my work to make the activities more attractive". (S8)

"I think that computer-based exercise is more interesting, more attractive to children. However, we need to exercise some restraint in this realm because, as we know, children are spending more and more time with telephones, tablets and TV sets at home". (S10)

Even though they stressed the priority of therapy delivered in the form of traditional meetings, the students also emphasized some benefits of this form of therapy, such as improving small motor skills and sensory stimulation.

"I am in favour of traditional speech therapy aids. Multidimensionality, different textures, colours and the use of various design forms and techniques make children not only interested in particular aids, but also offers them some sensory stimulation. For this reason, I do not exclude therapeutic apps, quite the contrary. I think that they enrich traditional speech therapy activities in an interesting way". (S2)

“(...) These tasks should aim to add variety to your session rather than being the only form of activities proposed. Bringing small items from 
one box to another, opening cardboard boxes and uncovering the memory pictures improve small motor skills much more than solving tablet tasks". (S6)

\section{Speech therapy students' plans for the use of ICTs as part of their future practice, as declared by the respondents.}

All students have declared that information and communication technologies provide them with new tools and working methods. They have said that they would diversify their activities for children by using interactive exercises, would use them for children fed up with over-used materials or as a reward for good work during regular exercises.

Most of the students stated that this was a good solution for home speech therapy exercises between meetings with a speech therapist at their office.

"I think children should practice previously acquired skills, for example, by receiving mobile homework". (S7)

"(...) you can share a file with a child for them to do tasks at home. It is certainly much more interesting for them than tasks written on a piece of paper. The child exercises more often, which positively contributes to the effect of speech therapy". (S3)

According to one of the students, another fact in favour of such a solution is that parents sometimes cannot take time to help their children perform the assignments recommended by speech therapists on a consistent basis.

"Moreover, it is a good solution for parents who are not always able to assist their children in consolidating the covered language material. Although this can take as little as 10-15 minutes, sometimes they have no spare time to do that. The use of an application and possible support from the parent can greatly facilitate this process (...)". (S2)

If a child does speech therapy exercises at home, the parent should actively participate in this process, observing and verifying 
the effects. However, if parents cannot get involved so, the built-in self-testing feature within interactive exercises automatically verifies the answers provided by the child.

"Another advantage is that (...) children learn to independently monitor and identify correct and incorrect answers. This facilitates self-control, which is very important from the perspective of supporting a child's motivation. This feedback helps children verify their progress themselves". (S2)

The students claim that in the future, the newly acquired skills to use technology in their practice will allow them to continue their therapy activities with children not only "in the case of a closure", but also when direct contact with children is difficult, e.g. in the case of a chronic illness or the need for a longer stay abroad.

"Providing children with remote activities that use applications is an option I will certainly use frequently in my future career. I believe this is a great solution in particular if the child is sick and cannot attend therapy sessions". (S8)

\section{Conclusion}

The shut-down of psychological-pedagogical counselling centres has been unprecedented in Poland. In the initial period of the pandemic, most speech therapists hoped that this would be a temporary phenomenon that would end quickly and that the short-term interruption of stationary therapy meetings eventually would not greatly affect the effects of the therapy work. When the period of the temporary closure was extended, therapists faced the risk that this new situation could be a new therapeutic reality rather than a temporary event. Due to the pandemic and the inability to work directly with children, speech therapists have had to become more involved in the world of information and communication technologies. This was also the case with the students participating in this study. The 
results of the study show that this crisis has become an opportunity for them to develop skills needed to use ICT tools in their future careers. They have recognised that information and communication technologies can be valuable tools that improve everyday practice. Well selected digital aids may offer some advantages. However, the use of information and communication technologies should be implemented primarily due to their effectiveness in supporting therapy work.

\section{References}

Jatkowska J., Rozwój językowy dziecka a b-learning, [in:] Annales Universitatis Paedagogicae Cracoviensis. Studia de Cultura, Vol. 10, No. 4/2018, pp. 125-140.

Juszczyk S., Zając W., Komputerowa edukacja uczniów z zaburzeniami w czytaniu i pisaniu, "Śląsk", Katowice 1997.

Łaszczyk J. (Ed.), Komputer w kształceniu specjalnym, Wydawnictwa Szkolne i Pedagogiczne, Warsaw 1998.

Pyżalski J., Wstęp, [in:] Edukacja w czasach pandemii. Z dystansem o tym, co robimy obecnie jako nauczyciele, ed. J. Pyżalski, EduAkcja, Warsaw 2020, pp. 2-6.

The Regulation of the Minister of National Education of 25 July 2019 on the standard of training for pedagogical practice. (JOURNAL OF LAWS 2019 NO. 1450).

The Regulation of the Minister of National Education of 20 March 2020 on special solutions in the period of temporary limitation of the operation of educational institutions to prevent, counteract and combat COVID-19. (Journal of Laws 2020, No. 493).

Siemieniecki B., Komputerowa diagnostyka i terapia pedagogiczna - zarys problemu, [in:] Komputer w diagnostyce i terapii pedagogicznej, ed. B. Siemieniecki, Wydawnictwo Adam Marszałek, Torun 1999, pp. 9-23.

Siemieniecki B., Zastosowanie technologii informacyjnej w pedagogice specjalnej, [in:] Pedagogika medialna, t. 2, red. B. Siemieniecki, Wydawnictwo Naukowe PWN, Warsaw 2007, pp. 52-62.

Stake R.E., Jakościowe studium przypadku, Trans. M. Sałkowska, [in:] Metody badań jakościowych. T. 1, ed. N.K. Denzin, Y.S. Lincoln, Wydawnictwo Naukowe PWN, Warsaw 2020.

Surowaniec J., Zastosowania informatyki w logopedii, [in:] Opuscula Logopaedica: in honorem Leonis Kaczmarek, Ed. S. Grabias, L. Kaczmarek, Wydawnictwo UMCS, Lublin 1993, pp. 112-121. 
Surowaniec J., Dekada informatyczna w rozwoju polskiej logopedii 1986-1996, Logopedia No. 23/1996, pp. 183-189.

Szurek M., Czy wspótczesny logopeda powinien wykorzystywać multimedia w terapii logopedycznej?, [in:] Zastosowanie nowych mediów w edukacji dzieci i młodzieży, Ed. E. Brzyszcz, S. Koziej, Uniwersytet Jana Kochanowskiego, Kielce 2017, pp. 133-143.

Waligóra-Huk A., Programy multimedialne jako narzędzia wykorzystywane przez nauczycieli w terapii pedagogicznej, [in:] Edukacja a nowe technologie w kulturze, informacji i komunikacji, Ed. D. Siemieniecka, Wydawnictwo Naukowe Uniwersytetu Mikołaja Kopernika, Toruń 2015, pp. 343-354.

Żuchelkowska K., Edukacyjne programy komputerowe w kształtowaniu prawidłowej wymowy $u$ dzieci, [in:] Edukacja a nowe technologie w kulturze, informacji i komunikacji, Ed. D. Siemieniecka, Wydawnictwo Naukowe Uniwersytetu Mikołaja Kopernika, Toruń 2015, pp. 329-341. 